
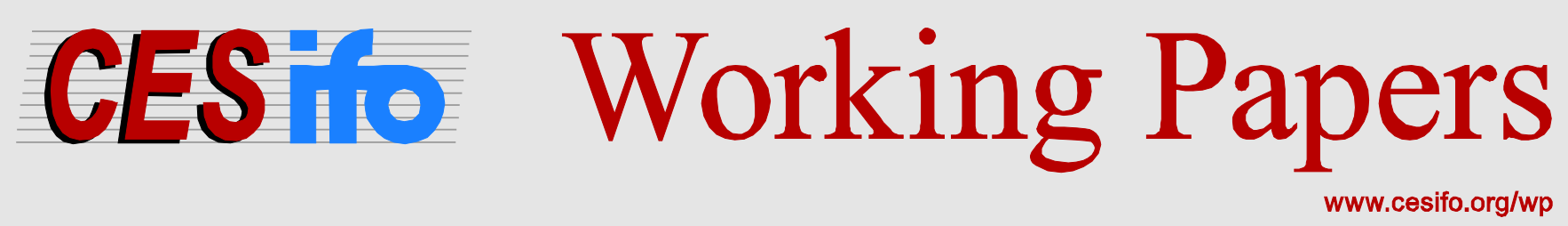

\title{
The Female Vote and the Rise of AKP in Turkey
}

\author{
Jan Fidrmuc \\ Çiğgdem Börke Tunalı
}

\author{
CESIFO WORKING PAPER NO. 5226 \\ CATEgory 2: Public CHOICE \\ FEBRUARY 2015
}

An electronic version of the paper may be downloaded

- from the SSRN website:

- from the RePEc website:

- from the CESifo website:

WWW.SSRN.com

www.RePEc.org

www.CESifo-group.org/wp 


\title{
The Female Vote and the Rise of AKP in Turkey
}

\begin{abstract}
Differences between the voting behavior of men and women have become one of the most significant issues in social science research in recent years. In this study, we examine whether there is gender gap in voting behavior in Turkey. Using European Social Survey data, we find that education level and religiosity are the main determinants of voting behavior of both men and women in Turkey. There are significant differences between the genders, nevertheless. In particular, the effect of education on the support for the Justice and Development Party (AKP) and the Republican People's Party (CHP) among male and female voters was different in the general election held in 2002. We argue that this outcome may be driven by the different labormarket implications of Islamization for male and female workers with intermediate skills.
\end{abstract}

JEL-Code: O150, P480, Z120.

Keywords: gender gap, voting, Turkey, Justice and Development Party (AKP), Republican People’s Party (CHP), democracy, Islam.

\author{
Jan Fidrmuc* \\ Department of Economics and Finance \\ Brunel University \\ United Kingdom Uxbridge, UB8 3PH \\ Jan.Fidrmuc@brunel.ac.uk
}

\author{
Çiğdem Börke Tunalı \\ Department of Economics \\ Faculty of Economics \\ Istanbul University / Turkey \\ cbtunali@istanbul.edu.tr
}

*corresponding author

February 2015

We received helpful comments and suggestions from Charles Grant, Philipp Harms, Arye Hillman, Nicola Maaser, Olga Zaikowska, as well as seminar/conference participants at Brunel University, the European Public Choice Society conference in Cambridge and the Silvaplana Workshop in Political Economy. 


\section{Introduction}

Gender differences in political attitudes and voting behavior have gained importance with the enfranchisement of women at the beginning of the twentieth century. The political "gender gap" has three different meanings. It may refer to gender differences in mass political participation (falling in recent years), differences between men's and women's votes (electoral gap) and different party identification of men and women (partisan gap) (Hill, 2003: 69; Conover, 1988: 985). For the purpose of our study, we use the term gender gap to denote the different voting behavior of men and women.

Although the gender gap in voting behavior has significant effects on the results of elections both in developed and developing countries, almost all of studies investigate this phenomenon for developed countries. Unlike the existing studies, we examine the gender gap in voting behavior in the case of voting political behavior of Turkish men and women, using the $2^{\text {nd }}$ and $4^{\text {th }}$ waves of the European Social Survey (ESS) carried out in 2004 and 2008, respectively. Hence, our study fills two important gaps in the literature by considering a country that is, at the same time, both developing and Muslim.

The most dramatic political development in Turkey's recent history has been the rise of the Justice and Development Party (known as AKP, its Turkish acronym), which was founded in 2001 as a moderately Islamic party. Departing from the previously mainly secular orientation of Turkish mainstream political parties, the AKP advocates a greater role for religious (Islamic) values in the public and private life. The AKP scored a landslide victory in the 2002 election, when it won 34 percent of votes and captured almost two thirds of seats in the parliament (Turkish electoral rules require parties to receive at least $10 \%$ of all votes to be represented in the parliament; that that fail to do so see their votes redistributed to the parties that meet this threshold). This was followed by further electoral successes in 2007 and 2011, when AKP saw its support reach 47 and 50 percent, respectively. In 2014, the AKP leader and standing Prime Minister, Recep Tayyip Erdoğan, won in the first round of the presidential election with $52 \%$ of the vote and became the first directly-elected President of Turkey. The AKP rule has been characterized by increased political assertiveness bordering on authoritarianism, especially in domestic political affairs. Since Erdoğan's election as President, furthermore, the country has been slowly moving towards a presidential system of government, with the Prime Minister taking on a distinctly subordinate role in national policy making.

A traditional and conservative interpretation of Islamic norms ascribes different roles to men and women in most aspects of everyday life, and it gives much more power to men than to women. 
As a result, women's participation in politics, the labor market, social life and/or their equality with men in the legal system are often circumscribed in Muslim countries. Notable examples of such conservative attitudes include the restrictions on women's dress code and labor-market participation, education, property and inheritance rights, ability to testify in a court of law on equal terms with men, ability to marry non-Muslims (allowed for men but not for women), entitlements to seek divorce and/or custody over children, or even issues as basic as being allowed to leave one's house unaccompanied by a male relative or to drive a car. In postOttoman Turkey, comprehensively equal rights for men and women have been adopted in law and, to a large extent, also practice. Yet, since the AKP's rise, the government's actions and pronouncements increasingly appear to depart from this. ${ }^{4}$

Because of the different roles ascribed to men and women in Muslim societies, we are specifically interested whether we can observe any gender gap in the political support for the main Turkish political parties, and whether this gender gap depends on male and female voters' socio-economic background such as education and occupation. The results of our analysis suggest that education and religiosity are the main drivers of voting behavior: votes for the AKP increase with religiosity and fall with education, both among male and female voters. When we allow for a non-linear effect of education, however, we observe a remarkable difference between men and women in the 2002 election: while formal education always translates into lower support for AKP among female voters, the pattern is hump-shaped for men. The peak support for AKP among men is attained at approximately five years of education, which, in Turkey, corresponds to completed primary school education. The pattern of support for the Republican People's Party (CHP), the main opposition, and broadly secular party, is roughly the reverse of that for the AKP.

The remainder of the paper proceeds as follows. In the next section, we briefly explain the existing literature and the reasons behind the gender gap in voting behavior. In section 3, we express our data sources and methodology. In section 4, we discuss our empirical results in detail and, in section 5, we conclude.

\footnotetext{
${ }^{4}$ As prime minister, Erdoğan, for example, was quoted as suggesting that women should have at least three and ideally five children, stating that he did not believe in men and women being equal (for both, see "Erdogan the Misogynist: Turkish Prime Minister Assaults Women's Rights," Spiegel Online, 19 June 2013, http://www.spiegel.de/international/europe/turkish-prime-minister-erdogan-targets-women-s-rights-a-839568.html) and equating abortion with murder ("Turkey PM Erdogan sparks row over abortion," BBC News, 1 June 2012 , http://www.bbc.co.uk/news/world-europe-18297760). Deputy Prime Minster Arinc, more recently, suggested that women should not laugh in public because doing so was haram (prohibited by Islam), they should not be inviting in their attitudes and should protect their chasteness (see "Turkish Deputy Prime Minister Tells Women not to Laugh in Public," Huffington Post, 8 June 2014, http://www.huffingtonpost.com/harut-sassounian/turkish-deputy-primemini_b_5656807.html).
} 


\section{Literature Review}

The political attitudes of women have become a hotly debated issue as women started to receive the right to vote at the beginning of the twentieth century (the first country to introduce women's suffrage being New Zealand, in 1893). In this period, it was speculated that women's vote would be distinctive and induce dramatic changes to party fortunes (Hill, 2003: 70). During the 1950s and 1960s, the difference between the men's and women's votes was modest but nonetheless women were more inclined to support conservative parties both in Western Europe and the United States. This phenomenon is referred to as the "traditional gender gap" (Inglehart-Norris, 2000: 443).

At the end of the 1970s and during the early 1980s, the traditional gender gap seemed to disappear and women begun to move to the left of men in the United States and in many European countries (Manow-Emmenegger, 2012: 10; Iversen-Rosenbluth, 2006: 12). This new cleavage between men's and women's political attitudes came to be called the "modern gender gap" (Inglehart-Norris, 2000: 444). Since the political differences between men and women are not identical across countries, recent studies of the gender gap have often reached contradictory results about the nature and the extent of the phenomenon.

Previous studies have put forward several explanations of the differing political attitudes of men and women. One of the earliest explanations for the gender gap, namely socialization, emphasizes the childhood experiences of men and women (Studlar et al., 1998: 782). According to this approach, political differences between men and women result from the sex-role conditioning and contrasting moral values conveyed to boys and girls by their parents (ManzaBrooks, 1998: 1240). As a consequence of this traditional socialization, based on the belief that the main responsibility of women is child rearing, the protection of life and cooperative decision making become more significant for women than men (Alexandre, 2004: 548).

The second approach to gender differences in political attitudes is based on the women's autonomy thesis and asserts that women who are the most autonomous from men have a tendency to differ the most from men in their political behaviors (Howell-Day, 2000: 860). In Becker's influential study on family (1985), it is assumed that the interests of family members are fully harmonized and therefore their political attitudes are expected to be the same. However, because of the differences between the interests of divorced and single women's and the others, some researchers have indicated that Becker's model becomes inaccurate when the rising divorce rates are taken into account (Iversen-Rosenbluth, 2006; Aidt-Dallal, 2008). Indeed, with 
the rising divorce rates since 1960s, a number of analysts have found evidence in favor of women's autonomy thesis (Edlund-Pande, 2002; Iversen-Rosenbluth, 2006).

The third approach to explaining the gender gap in political attitudes focuses on women's laborforce participation. This approach observes that although rising participation of women in the labor force has strengthened the position of women, it has not resulted in full equality in the labor market, political life or family. This explains why women are more concerned about unequal treatment and tend to be more leftist than men (Togeby, 1994: 217). According to this approach, there are three different ways in which increasing labor force participation of women results in a gender gap in political behavior (Manza-Brooks, 1998: 1243). First, the integration of women in the labor force exposes them to policy debates and other information about political campaigns. Hence, political awareness of women rises with their participation in the labor force. Second, since paid employment exposes women to gender inequalities, women tend to support political activism and feminist political goals. Finally, women are more dependent on the public sector for employment than men and they rely much more on social programs for supporting their families. Since leftist parties are generally more biased towards redistributive policies than the rightist parties, working women are apt to vote for the leftist parties.

Increasing labor force participation plays a crucial role in the Developmental Theory of the Gender Gap which has been proposed by Inglehart and Norris (2000). This theory states that in traditional societies, women are dissuaded from participating in the labor force since child bearing and child rearing are regarded as the main aims of women. However, in post-industrial societies, increasing labor force participation of women and other cultural changes have had dramatic impact on women's voting behavior.

The fourth explanation of political differences between men's and women's attitudes suggests that the main reason behind the gender gap is the feminist identity and consciousness (Conover, 1988: 988). Conover states that in the absence of feminism, women's values are dominated by male-oriented values. However, by becoming a feminist, women realize their basic values and form their own attitudes on political issues. According to this approach, feminists generally advocate egalitarian attitudes and thus support left-wing parties far more than non-feminists (Bergh, 2007: 238).

The final approach propounds two alternative hypotheses about this phenomenon (KaufmannPetrocik, 1999: 864-866): the Attitude Hypothesis and the Salience Hypothesis. While the Attitude Hypothesis argues that the gender gap stems from the distinct preferences of men and women on different political issues, the Salience Hypothesis asserts that the main reason of the 
gender gap is the differing weights men and women apply to political issues. For example, while most women may prefer increased social welfare spending and consider abortion as one of the most important issues in determining their votes, most men may prefer decreased social welfare spending and give relatively less weight to abortion in their voting decisions (Chaney, 1998: 312). Similarly, economic issues can have differential impacts on men's and women's political choices. As stated by Welch and Hibbing (1994), in contrast to men who behave egocentrically and consider their own economic circumstances in their voting decisions, women have a tendency to behave sociotropically and to take into account the country's economic conditions instead of their family's while determining their political choices. Although the Attitude and the Salience Hypotheses shed some light on the different political attitudes of men and women about policy issues that directly relate to a person's gender, they are incapable of explaining different political choices about issues in which gender does not play a role. Thus, other socioeconomic and cultural variables should be taken into account when dealing with issues that are not directly related to a person's gender (Bergh, 2007: 239).

Given that few Muslim countries are democracies with free and fair elections, it is not surprising that there is limited literature on the determinants of electoral outcomes in Muslim countries. Nevertheless, the sea change to Turkish politics brought about by the AKP victory in 2002 has resulted in some (limited) interest in the background of AKP's rise. Çarkoğlu and Hinich (2006) emphasize the role played by the main cleavages in Turkish politics and argue that the Islamism vs secularism and Turkish vs Kurdish nationalism dimensions matter more than the standard left-right dimension dominant in Western politics. Çarkoglu (2012), in turn, argues that the rise of AKP has been attributable to ideological rather than to economic concerns of voters. Başlevent, Kirmanoğlu and Şenatalar (2005) consider voting intentions and find that AKP supporters include mainly young voters, in particular males, and those who are not in favor of Turkey's entry into the European Union.

As the preceding discussion illustrates, much of the literature on the differences in political preferences of male and female voters focuses on advanced democratic countries, with studies on Muslim countries being particularly rare. ${ }^{5}$ In this paper, we seek to help fill this gap.

\section{Data and Methodology}

Our empirical analysis is based on individual survey data from the European Social Survey (ESS). The ESSs are carried out every two years in around 30 countries in Europe and its

\footnotetext{
${ }^{5}$ Appendix $\mathrm{C}$ summarizes the main contributions to the literature.
} 
neighborhood (not all countries feature in every wave). They follow a unified methodology and use the same basic questionnaire (while allowing for country-specific questions). The surveys address a wide range issues such as media exposure, political interest and participation, economic, political and social attitudes, and collect also detailed information on socio-economic characteristics of the respondents and their households. Importantly, the ESSs include retrospective questions on the respondents' voting behavior in the most recent election. For Turkey, voting behavior is addressed in waves 2 (2004) and 4 (2008), corresponding to the 2002 and 2007 elections, respectively. The ESSs feature 1-2 thousand respondents per country; we have 1156 observations with information on voting behavior in the $2^{\text {nd }}$ wave and 1304 in the $4^{\text {th }}$ wave.

The dependent variable equals 1 if the respondent voted for the party in question in the last election and zero otherwise. We consider the two main parties, the AKP and the CHP: these were the only two parties to be represented in the parliament following the 2002 election (they were joined by the Nationalist Movement Party, MHP, in 2007 and 2011, as well as by a number of independent MPs in every election). We include a number of explanatory variables which capture socio-economic characteristics of the respondents: age, gender, number of years of education, marital status, household composition, urban vs rural residence, economic situation of the household, labor-market status of the respondent during the last week, belonging to an ethnic minority (which, in Turkey, mainly captures the Kurds), and religiosity. Detailed explanations of these variables are in Appendix A. The regressions are estimated using the logit model.

\section{Empirical Results}

We estimate a number of regressions for each political party that participated in the 2002 and 2007 elections. We only report the regression results for Justice and Development Party (henceforth AKP) and Republican People's Party (henceforth CHP). These two political parties together received approximately 54\% and 68\% of total votes in the 2002 and 2007 elections, respectively (see Appendix B). ${ }^{6}$ They represent two contrasting political views: the AKP is a right-wing party while the CHP represents the left-wing side of the spectrum. Furthermore, with just over 1000 observations per wave, the regressions for the other parties suffer from low numbers of observations and are therefore bound to be less reliable. ${ }^{7}$

\footnotetext{
${ }^{6}$ The regression results for other parties are available upon request.

${ }^{7}$ An additional issue is that many of our explanatory variables take the form of dummies. For parties chosen by only a few dozen respondents, many of these end up being dropped.
} 
We estimate regressions relating voting for each party to the respondents' socio-economic characteristics including gender, age, years of education, labor-market participation, place of residence, living with husband/wife/partner, having children in the household, belonging to an ethnic minority and subjective perception about the household's income. To control for the effect of religiosity on voting behavior, we add a set of dummy variables that capture how often the respondents pray (results with self-reported degree of religiosity are very similar). All of the regressions are estimated for both genders together as well as for male and female voters separately.

Table 1 shows the results of regressions with socio-economic variables only (i.e. omitting religiosity) to explain the determinants of voting for AKP. The first three models show the results of regressions estimated with the ESS 2 data set, while the last three models show the results based on ESS 4, corresponding to the 2002 and 2007 elections, respectively.

Gender does not have an effect on the votes of AKP in either the 2002 or 2007 election (see columns 1 and 4). Few of the remaining variables (age, living with husband/wife/partner, place of residence and belonging to an ethnic minority) are statistically significant. However, an important difference appears with respect to education when we consider male and female votes in 2002 separately. The effect of education for males is hump-shaped: more years of formal education initially translate into greater support for AKP, before the effect levels off and becomes negative. The maximum effect is attained at just over 5 years of education, which, in Turkey, is equivalent to completed primary education. The effect for women, in contrast, is effectively negative throughout: it is u-shaped but the minimum is attained at 19 years (postgraduate level), which very few women possess. In other words, among women more education always implies lower support for the AKP. For men the effect is the initially reverse, with support for AKP rising with education, until an intermediate level of education.

Figure 1 depicts the distribution of education, by year, for men and women. Women are more represented at the bottom of the distribution: staggering 19 percent report to have no education at all, compared to 7 percent of men. Most respondents, 39 percent of men and women alike, completed only the compulsory primary education. Middle school, which required further 3 years, was not compulsory until 1997, so that many of the ESS respondents finished their education when only 5 years of schooling was mandatory (as of 2012, compulsory education entails 12 years). The next smaller peak, at 11 years, corresponds to completed high school, a level that is attained by $15 \%$ of males and $12 \%$ of females in our data. Only relatively few attain more than high-school education, with university (at 15 years) completed by $4 \%$ of men and $3 \%$ of women. This, effectively, means that nearly $50 \%$ of men and some $65 \%$ of women in Turkey 
have between 0 and 5 years of education. In other words, the divergent effect of education on voting behavior of male and female voters affects a large share of Turkish voters.

The different relationship between education and support for AKP among low-skilled men and women may stem from the fact that men with low level of education can benefit from lowskilled women being excluded from the labor market, as is likely to happen if Islamic social norms become more prevalent in Turkey. ${ }^{8}$ Therefore, such men could expect to see their labormarket outcomes improving under an AKP government. Women, whether low skilled or high skilled, in contrast, stand to gain little, as far as their labor-market position is concerned, from voting for the AKP.

Interestingly, the aforementioned effect of education can only be observed during the 2002 election. In 2007, education has a negative effect on all voters (and, in unreported regression with education featuring linearly, on males and females too); it does not have a different effect on the men's and women's votes for AKP. Seemingly, once the AKP assumed power, the voting behavior of males and females voters has converged.

Table 2 shows the results of the regressions in which we use both socio-economic variables and the dummy variables that represent respondents' religiosity. Specifically, we use a question on how often respondents pray; the answers to this question are summarized in Figure 2. Clearly, Turkey is a very religious society, with 65 percent of men and 77 percent of women claiming to pray every day. Nevertheless, we observe some change over time, with the share of those who pray every day falling slightly between 2004 and 2008 while the shares of those praying only on religious holy days rises (these figures are available upon request).

The regression results with religiosity are very similar to the previous results. As it is expected, people's attitude about religion is one of the most significant determinants of voting for AKP. Accordingly, respondents who pray rarely or never do not vote for AKP. Thus, religiosity is a crucial determinant of the support for AKP. As in the previous regressions, the gender dummy does not have an effect on the votes for AKP. Hence, taking into account religiosity does not change the results in respect to the gender gap in voting behavior. The differentiated effect of the quadratic polynomial of education, nevertheless, occurs also when controlling for religiosity. The pattern for men is again hump-shaped while that for women is u-shaped, with the respective turning points attained at almost identical education levels as in the preceding analysis without religiosity.

\footnotetext{
${ }^{8}$ Since the average educational attainment of women is significantly lower than that of men, low skilled men can face considerable competition from women that are active participants in the labor market.
} 
Tables 3 and 4 show the results of regressions that we estimate for the CHP. As in the previous analysis for AKP, we first take into account only socio-economic variables and then add religiosity as a determinant of voting behavior. As in tables 1 and 2, the first three models show the results of regressions estimated by using ESS 2, while the last three models show the results of regressions estimated using ESS 4.

Similar to the analysis for AKP, education plays an important role in determining support for the CHP. For all voters, the effect of education appears essentially positive. When considering the two genders separately, the pattern for males is u-shaped while that for females is hump-shaped, mirroring the results for the AKP. The lowest support among males is attained at just under 6 years of education. For females, the maximum is at over 11 years of formal education (equivalent to a high-school diploma). The pattern is very similar again when we take into account religiosity. As with the AKP support, the differentiated effect of education disappears in the 2007 election. Nevertheless, gender does appear as a statistically significant determinant of voting for CHP in the 2007 election in the regression with all voters: males are significantly less likely to vote for this party than females. This indicates that a gender gap in voting for CHP did appear in that year. Since the CHP is a center-left party and tends to support redistributive policies, this result is compatible with the view that women generally advocate egalitarian attitudes and vote for leftist parties. Finally, respondents who rarely or never pray are significantly more likely to vote for the CHP. Thus, as voting for AKP, religiosity is an important determinant of voting for CHP.

In summary; the years of education and religiosity are the most important determinants of voting for AKP and CHP. Moreover, the effect of education on voting behavior is different for males and females in an important way in the 2002 election. While education has different effects on men's and women's votes, religiosity affects the voting behavior of men and women in the same way. Furthermore, there is a gender gap between men and women in terms of voting for the CHP, with women more likely to vote for this party than men.

\section{Conclusion}

The differences between the voting behavior of men and women have become one of the most controversial issues in political-behavior research in recent years. Although there are quite a number of studies which try to find out the reasons of the gender gap in voting behavior in developed countries, almost none of the analyses investigate this phenomenon in developing or in Muslim countries. 
In this study, we examine the voting behavior of Turkish voters in the 2002 and 2007 elections, which heralded and cemented, respectively, the rise to power of the Justice and Development Party (AKP). We are particularly interested in the differences between the voting behavior of male and female voters, given that Islamic cultural and social norms impose important restrictions on the behavior of both genders, with the restrictions on women's behavior rather more onerous. To the best of our knowledge, this is the first comprehensive analysis of gender differences in voting behavior in Turkey, and one of only few for Muslim countries in general.

According to our results, years of education and religiosity are both important determinants of men's and women's votes. While religiosity affects the votes of men and women in the same way, the effect of years of education differs with respect to gender. In particular, we find that the support for the AKP among female voters falls with increasing education while the pattern for males is non-monotonic, rising first, peaking around the equivalent of primary education (5 years of schooling) and only then falling. The support for the main opposition party, the Republican People's Party (CHP), is the opposite, hump-shaped for women and u-shaped for men, with almost the same turning point for men as in the case of the AKP support.

It is striking that this pattern only prevails in the 2002 election; in the subsequent 2007 election, education shows a negative (positive) effect on the votes for the AKP (CHP) for both men and women alike. Instead, a standard gender gap appears in the 2007 election, with female voters more likely to vote for the CHP than males. This differentiation between male and female voting behavior in 2007 may be driven by the fact that low-skilled men may benefit from restrictions being placed on labor-market participation by women (who are on average less skilled than men in Turkey). Hence, the rise of political Islam in Turkey may have been assisted by gender conflict in the labor market. 


\section{References}

Aidt, T. S., B. Dallal (2008). "Female Voting Power: The Contribution of Women's Suffrage to the Growth of Social Spending in Western Europe (1869-1960)." Public Choice 134, 391417.

Alexandre, L (2004). "Gender Gap.” Encyclopedia of Leadership, In: G. R. Goethals, G. J. Sorenson and J. M. Burns (eds), Sage Publications, 540-550.

Başlevent, C., H. Kirmanoğlu, B. Şenatalar (2005). "Empirical investigation of party preferences and economic voting in Turkey." European Journal of Political Research 44, 547-562.

Becker, G. S. (1985). "Human Capital, Effort, and the Sexual Division of Labor." Journal of Labor Economics, 3(1), Part 2, Trend's in Women's Work, Education and Family Building, S33-S58.

Bergh, J. (2007). "Explaining the Gender Gap: A Cross National Analysis of Gender Differences in Voting." Journal of Elections, Public Opinion and Parties, 17(3), 235-261.

Brooks, C., P. Nieuwbeerta, J. Manza (2006). "Cleavage-based Voting Behavior in Crossnational Perspective: Evidence from Six Postwar Democracies." Social Science Research, $35,88-128$.

Çarkoğlu, A. (2012). "Economic evaluations vs. ideology: Diagnosing the sources of electoral change in Turkey, 2002-2011.” Electoral Studies 31, 513-521.

Çarkoğlu, A. and M.J. Hinich (2006). "A spatial analysis of Turkish party preferences." Electoral Studies 25, 369-392.

Chaney, C. K., R. M. Alvarez, J. Nagler (1998). "Explaining the Gender Gap in US Presidential Elections, 1980-1992." Political Research Quarterly, 51(2), 311-339.

Conover, P. J. (1988). "Feminists and the Gender Gap.” The Journal of Politics 50(4), 985-1010.

Edlund L., R. Pande (2002). "Why Have Women Become Left-Wing? The Political Gender Gap and the Decline in Marriage." The Quarterly Journal of Economics 117(3), 917-961.

European Social Survey (2004). ESS Wave-2 2004-Turkey, www.europeansocialsurvey.org

European Social Survey (2008). ESS Wave-4 2008-Turkey, www.europeansocialsurvey.org

Finseraas, H., N. Jakobsson, A. Kotsadam (2012). "The Gender Gap in Political Preferences: An Empirical Test of a Political Economy Explanation.” Social Politics 19(2), 219-242.

Giger, N. (2009). "Towards a Modern Gender Gap in Europe? A Comparative Analysis of Voting Behavior in 12 Countries." The Social Science Journal 46, 474-492.

Hayes, B. C. (1997). "Gender, Feminism and Electoral Behaviour in Britain., Electoral Studies 16(2), 203-216.

Hill, L. (2003). "The Political Gender Gap: Australia, Britain and the United States.” Policy and Society 22(1), 69-96.

Howell, S. E., C. L. Day (2000). "Complexities of Gender Gap.” The Journal of Politics 62(3), 858-874.

Inglehart, R., P. Norris (2000). "The Developmental Theory of the Gender Gap: Women's and Men's Voting Behavior in Global Perspective." International Political Science Review 21(4), 441-463.

Iversen, T., F. Rosenbluth (2006). "The Political Economy of Gender: Explaining CrossNational Variation in the Gender Division of Labor and the Gender Voting Gap." American Journal of Political Science 50(1), 1-19.

Kaufmann, K. M., J. R. Petrocik (1999). "The Changing Politics of American Men: Understanding the Sources of the Gender Gap." American Journal of Political Science 
43(3), 864-887.

Kaufmann, K. M. (2002). "Culture Wars, Secular Realignment, and the Gender Gap in Party Identification." Political Behavior 24(3), 283-307.

Knutsen, O. (2001). "Social Class, Sector Employment, and Gender as Party Cleavages in the Scandinavian Countries: A Comparative Longitudinal Study, 1970-95." Scandinavian Political Studies 24(4), 311-350.

Manov, P., P. Emmenegger (2012). "Religion and Gender Vote Gap? Women's Changed Political Preferences from the 1970s to 2010.” ZeS-Arbeitspapier No: 01/2012, 1-45.

Manza, J. C. Brooks (1998). "The Gender Gap in US Presidential Elections: When? Why? Implications?" The American Journal of Sociology 103(5), 1235-1266.

Studlar, D. T., I. McAllister, B. C. Hayes (1998). "Explaining the Gender Gap in Voting: A Cross National Analysis." Social Science Quarterly 79(4), 779-798.

Togeby, L. (1994). "Political Implications of Increasing Numbers of Women in the Labor Force." Comparative Political Studies 27(2), 211-240.

Turkish Statistical Institute (2013). Justice and Election Statistics, www,tuik.gov.tr

Welch, S., J. Hibbing (1992). "Financial Conditions, Gender, and Voting in American National Elections." The Journal of Politics 54(1), 197-213. 
Figure 1 Years of education by gender

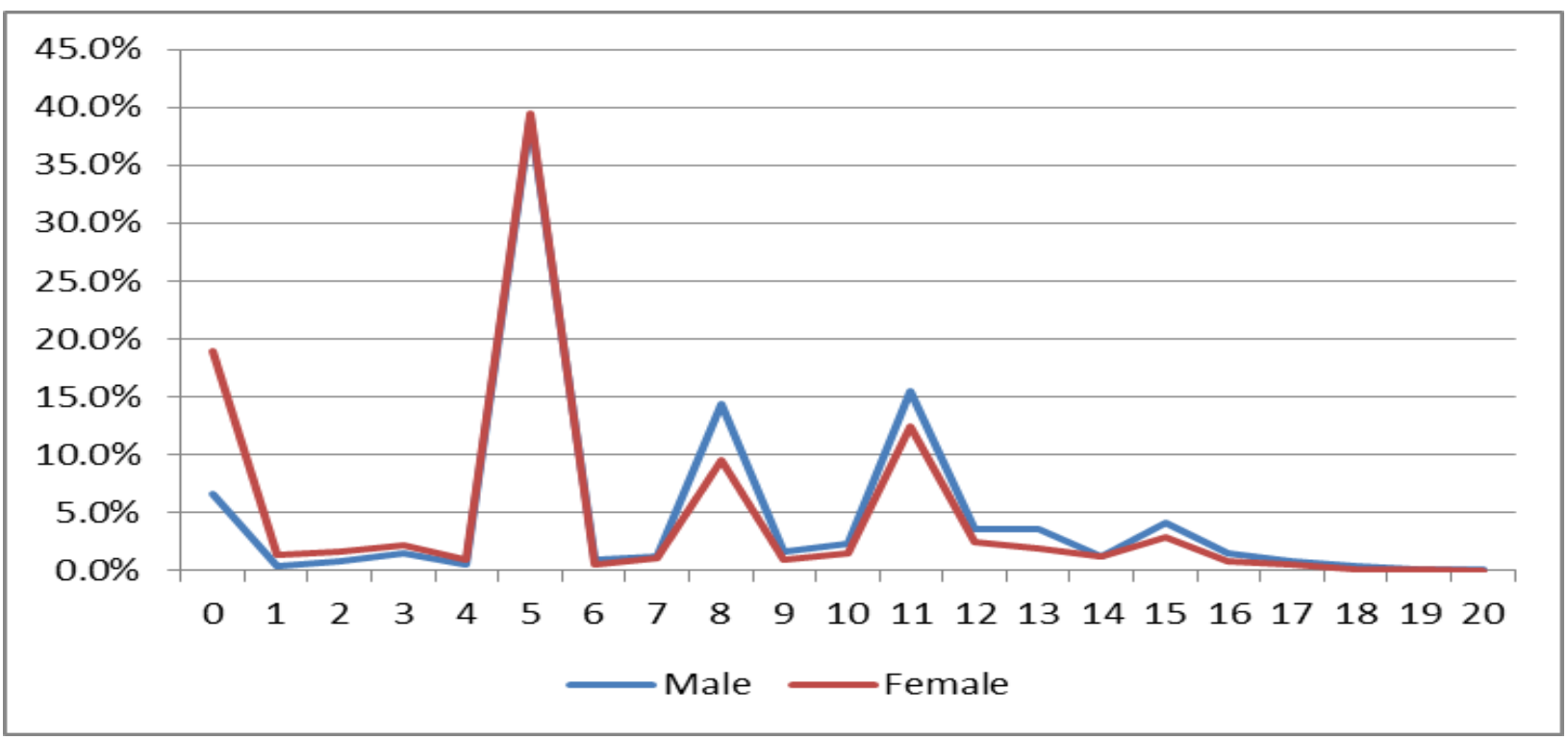

Notes: Primary education comprises 5 years and is compulsory. Middle school is completed at 8 years (and has been compulsory since 1997). 11 years corresponds to completed high school and 15 years is an undergraduate degree.

Figure 2 Religiosity

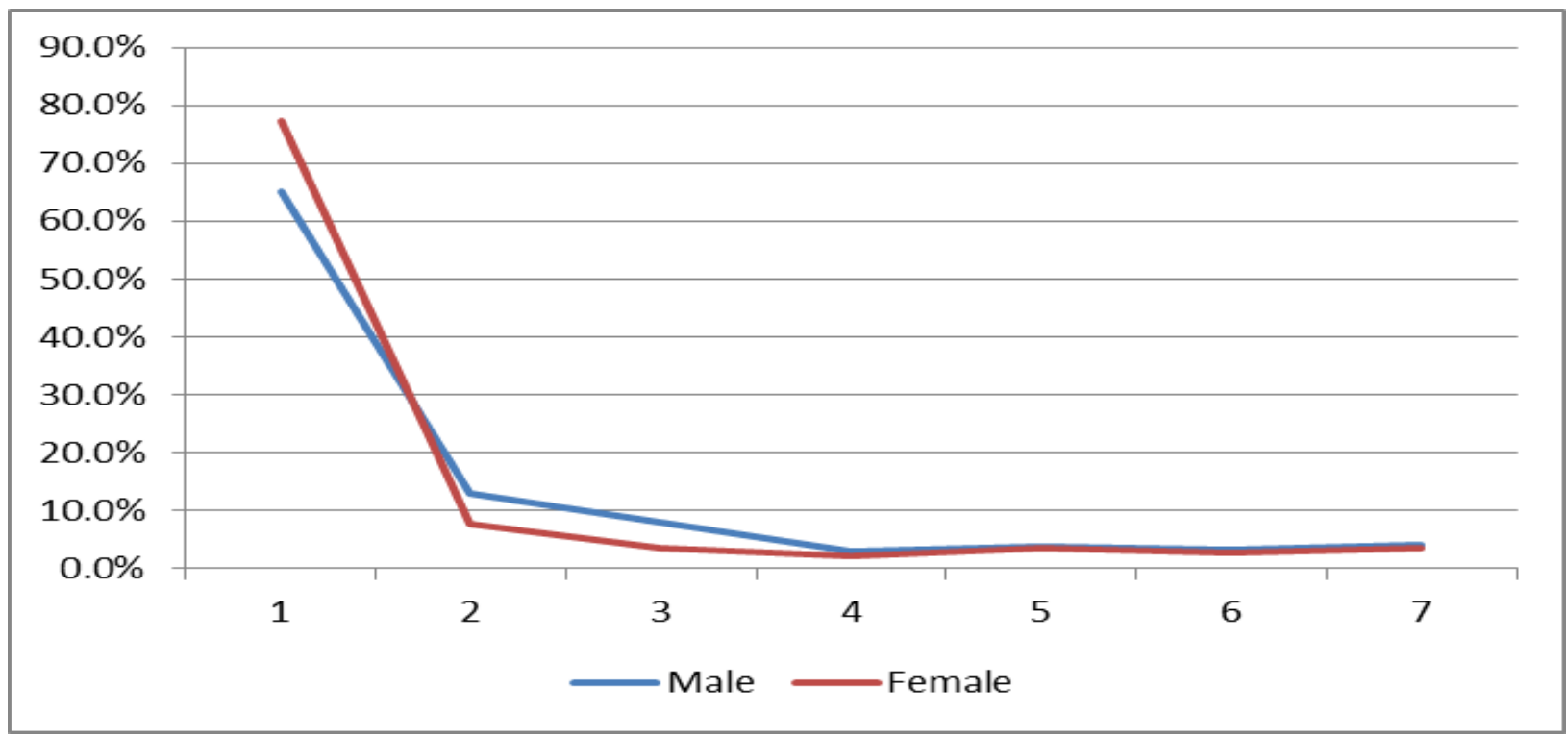

Notes: Responses to the question "How often pray apart from at religious services." The possible answers were every day (1), more than once a week (2), once a week (3), at least once a month (4), only on special holy days (5), less often (6), and never (7). 
Table 1 Determinants of Voting for AKP

\begin{tabular}{|c|c|c|c|c|c|c|}
\hline & \multicolumn{3}{|c|}{ ESS Wave 2 (2004) } & \multicolumn{3}{|c|}{ ESS Wave 4 (2008) } \\
\hline Male & $\begin{array}{r}0.0587 \\
(0.0535)\end{array}$ & & & $\begin{array}{r}0.0661 \\
(0.0533)\end{array}$ & & \\
\hline Age & $\begin{array}{r}-0.0143^{\star * *} \\
(0.0071)\end{array}$ & $\begin{array}{r}-0.0143 \\
(0.0116)\end{array}$ & $\begin{array}{r}-0.0120 \\
(0.0099)\end{array}$ & $\begin{array}{l}-0.0022 \\
(0.0065)\end{array}$ & $\begin{array}{r}-0.0053 \\
(0.0110)\end{array}$ & $\begin{array}{r}0.0093 \\
(0.0088)\end{array}$ \\
\hline Age sqrd & $\begin{array}{l}0.0001^{*} \\
(0.0001)\end{array}$ & $\begin{array}{r}0.0002 \\
(0.0001)\end{array}$ & $\begin{array}{r}0.0001 \\
(0.0001)\end{array}$ & $\begin{array}{l}0.00002 \\
(0.0001)\end{array}$ & $\begin{array}{l}0.00009 \\
(0.0001)\end{array}$ & $\begin{array}{r}-0.00010 \\
(0.0001)\end{array}$ \\
\hline $\begin{array}{l}\text { Education years } \\
\text { sqrd }\end{array}$ & $\begin{array}{r}-0.0010 \\
(0.0008)\end{array}$ & $\begin{array}{r}-0.0046^{* * *} \\
(0.0014)\end{array}$ & $\begin{array}{r}0.0009 \\
(0.0010)\end{array}$ & $\begin{array}{l}-0.0007 \\
(0.0008)\end{array}$ & $\begin{array}{r}-0.0014 \\
(0.0013)\end{array}$ & $\begin{array}{l}-0.0008 \\
(0.0012)\end{array}$ \\
\hline Household size & $\begin{array}{r}-0.0034 \\
(0.0097)\end{array}$ & $\begin{array}{r}0.0043 \\
(0.0148)\end{array}$ & $\begin{array}{l}-0.0088 \\
(0.0133)\end{array}$ & $\begin{array}{r}0.0061 \\
(0.0104)\end{array}$ & $\begin{array}{r}-0.0162 \\
(0.0157)\end{array}$ & $\begin{array}{r}0.0291^{*} \\
(0.0163)\end{array}$ \\
\hline $\begin{array}{l}\text { Children } \\
\text { (dummy) }\end{array}$ & $\begin{array}{r}0.0576 \\
(0.0434)\end{array}$ & $\begin{array}{r}-0.0037 \\
(0.0691)\end{array}$ & $\begin{array}{l}0.1059^{*} \\
(0.0581)\end{array}$ & $\begin{array}{r}0.0226 \\
(0.0396)\end{array}$ & $\begin{array}{r}0.0342 \\
(0.0627)\end{array}$ & $\begin{array}{r}0.0136 \\
(0.0530)\end{array}$ \\
\hline Town $^{(1)}$ & $\begin{array}{r}-0.0627 \\
(0.0422)\end{array}$ & $\begin{array}{l}-0.0639 \\
(0.0637)\end{array}$ & $\begin{array}{l}-0.0625 \\
(0.0587)\end{array}$ & $\begin{array}{r}-0.0388 \\
(0.0499)\end{array}$ & $\begin{array}{r}-0.0558 \\
(0.0791)\end{array}$ & $\begin{array}{r}-0.0362 \\
(0.0657)\end{array}$ \\
\hline Village $^{(1)}$ & $\begin{array}{r}0.0365 \\
(0.0424)\end{array}$ & $\begin{array}{l}-0.0530 \\
(0.0612)\end{array}$ & $\begin{array}{l}0.1247^{* *} \\
(0.0621)\end{array}$ & $\begin{array}{r}-0.0522 \\
(0.0396)\end{array}$ & $\begin{array}{l}-0.1119^{*} \\
(0.0579)\end{array}$ & $\begin{array}{r}0.0069 \\
(0.0574)\end{array}$ \\
\hline Farm/countryside ${ }^{(1)}$ & $\begin{array}{r}-0.2883 \\
(0.3032)\end{array}$ & $\begin{array}{r}-0.3427 \\
(0.3085)\end{array}$ & 0 (omitted) & 0 (omitted) & 0 (omitted) & 0 (omitted) \\
\hline Income: coping ${ }^{(2)}$ & $\begin{array}{r}0.0405 \\
(0.0590)\end{array}$ & $\begin{array}{r}0.0034 \\
(0.0948)\end{array}$ & $\begin{array}{r}0.0741 \\
(0.0805)\end{array}$ & $\begin{array}{l}-0.0536 \\
(0.0643)\end{array}$ & $\begin{array}{r}-0.1881^{* *} \\
(0.0958)\end{array}$ & $\begin{array}{r}0.0544 \\
(0.0884)\end{array}$ \\
\hline Income: difficult ${ }^{(2)}$ & $\begin{array}{r}0.0077 \\
(0.0641)\end{array}$ & $\begin{array}{l}-0.0924 \\
(0.1034)\end{array}$ & $\begin{array}{r}0.0914 \\
(0.0868)\end{array}$ & $\begin{array}{r}-0.0399 \\
(0.0671)\end{array}$ & $\begin{array}{r}-0.1509 \\
(0.1015)\end{array}$ & $\begin{array}{r}0.0445 \\
(0.0913)\end{array}$ \\
\hline Income: v.difficult ${ }^{(2)}$ & $\begin{array}{l}-0.0114 \\
(0.0700)\end{array}$ & $\begin{array}{l}-0.1069 \\
(0.1140)\end{array}$ & $\begin{array}{r}0.0293 \\
(0.0941)\end{array}$ & $\begin{array}{r}-0.0945 \\
(0.0729)\end{array}$ & $\begin{array}{r}-0.2385^{\star \star} \\
(0.1098)\end{array}$ & $\begin{array}{r}0.0249 \\
(0.1002)\end{array}$ \\
\hline Paid work ${ }^{(3)}$ & $\begin{array}{r}0.0174 \\
(0.0677)\end{array}$ & $\begin{array}{r}0.0350 \\
(0.0844)\end{array}$ & $\begin{array}{r}-0.0247 \\
(0.1277)\end{array}$ & $\begin{array}{r}0.0243 \\
(0.0951)\end{array}$ & $\begin{array}{r}-0.0026 \\
(0.1200)\end{array}$ & $\begin{array}{r}0.0934 \\
(0.1662)\end{array}$ \\
\hline Retired $^{(3)}$ & $\begin{array}{r}0.1244 \\
(0.0765)\end{array}$ & $\begin{array}{r}0.0704 \\
(0.0993)\end{array}$ & $\begin{array}{r}0.1462 \\
(0.1503)\end{array}$ & $\begin{array}{r}-0.0671 \\
(0.0998)\end{array}$ & $\begin{array}{r}-0.1439 \\
(0.1272)\end{array}$ & $\begin{array}{r}-0.0924 \\
(0.1838)\end{array}$ \\
\hline Homeworker ${ }^{(3)}$ & $\begin{array}{r}0.1139 \\
(0.0717)\end{array}$ & $\begin{array}{l}0.4798^{\star *} \\
(0.2111)\end{array}$ & $\begin{array}{r}0.0473 \\
(0.1034)\end{array}$ & $\begin{array}{r}0.1110 \\
(0.0999)\end{array}$ & $\begin{array}{r}-0.1400 \\
(0.3845)\end{array}$ & $\begin{array}{r}0.1154 \\
(0.1550)\end{array}$ \\
\hline Ethnic minority & $\begin{array}{r}-0.1780^{* * *} \\
(0.0599) \\
\end{array}$ & $\begin{array}{r}-0.1157 \\
(0.0909) \\
\end{array}$ & $\begin{array}{r}-0.2463^{* * *} \\
(0.0845) \\
\end{array}$ & $\begin{array}{r}-0.1906^{\star * \star} \\
(0.0613) \\
\end{array}$ & $\begin{array}{r}-0.1910^{* \star} \\
(0.0878) \\
\end{array}$ & $\begin{array}{r}-0.1908^{\star *} \\
(0.0895) \\
\end{array}$ \\
\hline
\end{tabular}

Marginal effects, with standard errors in parentheses. Significance: $* * * p<0.01: * * p<0.05 * \mathrm{p}<0.10$. Omitted categories:

(1) Resident in big city; (2) comfortable with current income; (3) last 7 days any other activity. 
Table 2 Determinants of Voting for AKP (with religiosity)

\begin{tabular}{|c|c|c|c|c|c|c|}
\hline & \multicolumn{3}{|c|}{ ESS Wave 2 (2004) } & \multicolumn{3}{|c|}{ ESS Wave 4 (2008) } \\
\hline & 1 & 2 & 3 & 4 & 5 & 6 \\
\hline Male & $\begin{array}{l}0.0764 \\
(0.0548)\end{array}$ & & & $\begin{array}{l}0.0641 \\
(0.0546)\end{array}$ & & \\
\hline Age & $\begin{array}{c}-0.0155^{\star *} \\
(0.0073)\end{array}$ & $\begin{array}{l}-0.0138 \\
(0.0119)\end{array}$ & $\begin{array}{l}-0.0140 \\
(0.0101)\end{array}$ & $\begin{array}{l}-0.0006 \\
(0.0067)\end{array}$ & $\begin{array}{l}0.0041 \\
(0.0113)\end{array}$ & $\begin{array}{l}0.0070 \\
(0.0090)\end{array}$ \\
\hline Age sqrd & $\begin{array}{l}0.0001^{*} \\
(0.0001)\end{array}$ & $\begin{array}{l}0.0001 \\
(0.0001)\end{array}$ & $\begin{array}{l}0.0001 \\
(0.0001)\end{array}$ & $\begin{array}{l}0.0000 \\
(0.0001)\end{array}$ & $\begin{array}{l}0.0000 \\
(0.0001)\end{array}$ & $\begin{array}{l}-0.0001 \\
(0.0001)\end{array}$ \\
\hline $\begin{array}{l}\text { Education years } \\
\text { sqrd }\end{array}$ & $\begin{array}{l}-0.0007 \\
(0.0008)\end{array}$ & $\begin{array}{l}-0.0043^{* * *} \\
(0.0014)\end{array}$ & $\begin{array}{l}0.0009 \\
(0.0010)\end{array}$ & $\begin{array}{l}-0.0006 \\
(0.0009)\end{array}$ & $\begin{array}{l}-0.0012 \\
(0.0013)\end{array}$ & $\begin{array}{l}-0.0007 \\
(0.0012)\end{array}$ \\
\hline Household size & $\begin{array}{l}-0.0027 \\
(0.0098)\end{array}$ & $\begin{array}{l}0.0032 \\
(0.0152)\end{array}$ & $\begin{array}{l}-0.0061 \\
(0.0135)\end{array}$ & $\begin{array}{l}0.0023 \\
(0.0107)\end{array}$ & $\begin{array}{l}-0.0236 \\
(0.0166)\end{array}$ & $\begin{array}{l}0.0260 \\
(0.0166)\end{array}$ \\
\hline $\begin{array}{l}\text { Children } \\
\text { (dummy) }\end{array}$ & $\begin{array}{l}0.0461 \\
(0.0440)\end{array}$ & $\begin{array}{l}-0.0068 \\
(0.0708)\end{array}$ & $\begin{array}{l}0.0806 \\
(0.0592)\end{array}$ & $\begin{array}{l}0.0362 \\
(0.0407)\end{array}$ & $\begin{array}{l}0.0292 \\
(0.0656)\end{array}$ & $\begin{array}{l}0.0501 \\
(0.0547)\end{array}$ \\
\hline Town ${ }^{(1)}$ & $\begin{array}{c}-0.0552 \\
(0.0433)\end{array}$ & $\begin{array}{l}-0.0571 \\
(0.0669)\end{array}$ & $\begin{array}{l}-0.0730 \\
(0.0600)\end{array}$ & $\begin{array}{l}-0.0471 \\
(0.0510)\end{array}$ & $\begin{array}{l}-0.0718 \\
(0.0822)\end{array}$ & $\begin{array}{l}-0.0337 \\
(0.0665)\end{array}$ \\
\hline Village $^{(1)}$ & $\begin{array}{l}0.0301 \\
(0.0430)\end{array}$ & $\begin{array}{l}-0.0692 \\
(0.0627)\end{array}$ & $\begin{array}{l}0.1111^{*} \\
(0.0634)\end{array}$ & $\begin{array}{l}-0.0487 \\
(0.0410)\end{array}$ & $\begin{array}{c}-0.1490^{* *} \\
(0.0611)\end{array}$ & $\begin{array}{l}0.0349 \\
(0.0598)\end{array}$ \\
\hline Farm/countryside ${ }^{(1)}$ & $\begin{array}{l}-0.2937 \\
(0.3075)\end{array}$ & $\begin{array}{l}-0.3552 \\
(0.3164)\end{array}$ & 0 (omitted) & 0 (omitted) & 0 (omitted) & 0 (omitted) \\
\hline Income: coping ${ }^{(2)}$ & $\begin{array}{l}0.0625 \\
(0.0592)\end{array}$ & $\begin{array}{l}0.0201 \\
(0.0954)\end{array}$ & $\begin{array}{l}0.0837 \\
(0.0816)\end{array}$ & $\begin{array}{l}-0.0568 \\
(0.0665)\end{array}$ & $\begin{array}{l}-0.1863^{*} \\
(0.1006)\end{array}$ & $\begin{array}{l}0.0436 \\
(0.0909)\end{array}$ \\
\hline Income: difficult ${ }^{(2)}$ & $\begin{array}{l}0.0289 \\
(0.0645)\end{array}$ & $\begin{array}{c}-0.0753 \\
(0.1049)\end{array}$ & $\begin{array}{l}0.0982 \\
(0.0880)\end{array}$ & $\begin{array}{c}-0.0445 \\
(0.0693)\end{array}$ & $\begin{array}{c}-0.1374 \\
(0.1072)\end{array}$ & $\begin{array}{l}0.0351 \\
(0.0936)\end{array}$ \\
\hline$\underset{(2)}{\text { Income: v. difficult }}$ & $\begin{array}{l}0.0066 \\
(0.0703)\end{array}$ & $\begin{array}{l}-0.0946 \\
(0.1156)\end{array}$ & $\begin{array}{l}0.0329 \\
(0.0952)\end{array}$ & $\begin{array}{l}-0.0939 \\
(0.0751)\end{array}$ & $\begin{array}{c}-0.2426^{\star *} \\
(0.1148)\end{array}$ & $\begin{array}{l}0.0303 \\
(0.1031)\end{array}$ \\
\hline Sick/disabled ${ }^{(3)}$ & $\begin{array}{l}0.2748 \\
(0.2200)\end{array}$ & $\begin{array}{l}0.3117 \\
(0.2410)\end{array}$ & 0 (omitted) & $\begin{array}{l}-0.2197 \\
(0.2739)\end{array}$ & $\begin{array}{l}-0.0083 \\
(0.3649)\end{array}$ & 0 (omitted) \\
\hline Retired $^{(3)}$ & $\begin{array}{l}0.1344^{*} \\
(0.0776)\end{array}$ & $\begin{array}{l}0.0860 \\
(0.1005)\end{array}$ & $\begin{array}{l}0.1789 \\
(0.1522)\end{array}$ & $\begin{array}{l}-0.0737 \\
(0.1025)\end{array}$ & $\begin{array}{l}-0.1478 \\
(0.1301)\end{array}$ & $\begin{array}{l}-0.1034 \\
(0.1917)\end{array}$ \\
\hline Homeworker ${ }^{(3)}$ & $\begin{array}{l}0.1235^{\star} \\
(0.0728)\end{array}$ & $\begin{array}{l}0.5446^{\star \star} \\
(0.2320)\end{array}$ & $\begin{array}{l}0.0642 \\
(0.1052)\end{array}$ & $\begin{array}{l}0.1136 \\
(0.1030)\end{array}$ & $\begin{array}{l}-0.1082 \\
(0.3812)\end{array}$ & $\begin{array}{l}0.0880 \\
(0.1636)\end{array}$ \\
\hline Ethnic minority & $\begin{array}{l}-0.1869^{\star \star *} \\
(0.0611)\end{array}$ & $\begin{array}{l}-0.1123 \\
(0.0930)\end{array}$ & $\begin{array}{l}-0.2670^{\star * *} \\
(0.0859)\end{array}$ & $\begin{array}{l}-0.1905^{\star * *} \\
(0.0645)\end{array}$ & $\begin{array}{l}-0.1479 \\
(0.0980)\end{array}$ & $\begin{array}{l}-0.2010^{* *} \\
(0.0916)\end{array}$ \\
\hline $\begin{array}{l}\text { Pray more than } \\
\text { once per week }\end{array}$ & $\begin{array}{l}-0.0468 \\
(0.0546)\end{array}$ & $\begin{array}{l}-0.1005 \\
(0.0719)\end{array}$ & $\begin{array}{l}0.0106 \\
(0.0915)\end{array}$ & $\begin{array}{l}-0.0786 \\
(0.0541)\end{array}$ & $\begin{array}{l}-0.0814 \\
(0.0713)\end{array}$ & $\begin{array}{l}-0.0877 \\
(0.0886)\end{array}$ \\
\hline $\begin{array}{l}\text { Pray } \\
\text { once per week }\end{array}$ & $\begin{array}{l}-0.0240 \\
(0.0730)\end{array}$ & $\begin{array}{l}-0.0039 \\
(0.0922)\end{array}$ & $\begin{array}{l}-0.0675 \\
(0.1321)\end{array}$ & $\begin{array}{l}-0.1267^{*} \\
(0.0710)\end{array}$ & $\begin{array}{c}-0.1865^{\star \star} \\
(0.0946)\end{array}$ & $\begin{array}{l}-0.1057 \\
(0.1137)\end{array}$ \\
\hline $\begin{array}{l}\text { Pray at least } \\
\text { once a month }\end{array}$ & $\begin{array}{l}-0.1224 \\
(0.1221)\end{array}$ & $\begin{array}{c}-0.1542 \\
(0.1566)\end{array}$ & $\begin{array}{l}-0.1118 \\
(0.2153)\end{array}$ & $\begin{array}{l}0.05787 \\
(0.1002)\end{array}$ & $\begin{array}{l}0.0876 \\
(0.1564)\end{array}$ & $\begin{array}{l}0.0741 \\
(0.1316)\end{array}$ \\
\hline $\begin{array}{l}\text { Pray only on } \\
\text { Special holidays }\end{array}$ & $\begin{array}{l}-0.0929 \\
(0.1366)\end{array}$ & $\begin{array}{c}0.12160 \\
(0.1938)\end{array}$ & $\begin{array}{l}-0.4505 \\
(0.2774)\end{array}$ & $\begin{array}{c}-0.1480^{* *} \\
(0.0752)\end{array}$ & $\begin{array}{l}-0.3948^{\star \star \star \star} \\
(0.1398)\end{array}$ & $\begin{array}{l}-0.0336 \\
(0.0959)\end{array}$ \\
\hline Pray less often & $\begin{array}{l}-0.4251^{\star * *} \\
(0.1180)\end{array}$ & $\begin{array}{c}-0.3625^{\star \star} \\
(0.1521)\end{array}$ & $\begin{array}{c}-0.4856^{\star *} \\
(0.1976)\end{array}$ & $\begin{array}{c}-0.2452^{* *} \\
(0.1211)\end{array}$ & $\begin{array}{c}-0.5845^{\star *} \\
(0.2715)\end{array}$ & $\begin{array}{l}-0.1363 \\
(0.1456)\end{array}$ \\
\hline Pray never & $\begin{array}{l}-0.3683^{\star * *} \\
(0.1301)\end{array}$ & $\begin{array}{c}-0.4190^{\star *} \\
(0.1694)\end{array}$ & $\begin{array}{l}-0.3363 \\
(0.2253)\end{array}$ & $\begin{array}{l}-0.5058^{\star * *} \\
(0.1088)\end{array}$ & $\begin{array}{l}-0.6107^{\star * *} \\
(0.1964)\end{array}$ & $\begin{array}{c}-0.4303^{\star * \star} \\
(0.1333)\end{array}$ \\
\hline
\end{tabular}

Marginal effects, with standard errors in parentheses. Significance: $* * * p<0.01$ : $* * p<0.05 * \mathrm{p}<0.10$. Omitted categories: $(1)$

Resident in big city; (2) comfortable with current income; (3) last 7 days any other activity. 
Table 3 Determinants of Voting for CHP

\begin{tabular}{|c|c|c|c|c|c|c|}
\hline & \multicolumn{3}{|c|}{ ESS Wave 2 (2004) } & \multicolumn{3}{|c|}{ ESS Wave 4 (2008) } \\
\hline & 1 & 2 & 3 & 4 & 5 & 6 \\
\hline Male & $\begin{array}{l}-0.0475 \\
(0.0305)\end{array}$ & & & $\begin{array}{l}-0.0689^{\star \star} \\
(0.0327)\end{array}$ & & \\
\hline Age & $\begin{array}{r}0.0104^{* *} \\
(0.0046)\end{array}$ & $\begin{array}{l}0.0130^{*} \\
(0.0074)\end{array}$ & $\begin{array}{l}0.0053 \\
(0.0058)\end{array}$ & $\begin{array}{c}0.0094^{\star \star} \\
(0.0047)\end{array}$ & $\begin{array}{c}0.0223^{\star \star *} \\
(0.0084)\end{array}$ & $\begin{array}{l}-0.0005 \\
(0.0057)\end{array}$ \\
\hline Age sqrd & $\begin{array}{l}-0.0001^{*} \\
(0.0000)\end{array}$ & $\begin{array}{l}-0.0001^{*} \\
(0.0001)\end{array}$ & $\begin{array}{r}-0.00002 \\
(0.0001)\end{array}$ & $\begin{array}{l}-0.0001 \\
(0.0000)\end{array}$ & $\begin{array}{l}-0.00022^{* * *} \\
(0.0001)\end{array}$ & $\begin{array}{l}0.00003 \\
(0.0001)\end{array}$ \\
\hline $\begin{array}{l}\text { Education years } \\
\text { sqrd }\end{array}$ & $\begin{array}{l}-0.0004 \\
(0.0004)\end{array}$ & $\begin{array}{l}0.0012^{*} \\
(0.0007)\end{array}$ & $\begin{array}{c}-0.0013^{* *} \\
(0.0006)\end{array}$ & $\begin{array}{l}0.0001 \\
(0.0005)\end{array}$ & $\begin{array}{l}0.0011 \\
(0.0009)\end{array}$ & $\begin{array}{l}0.0001 \\
(0.0007)\end{array}$ \\
\hline Household size & $\begin{array}{l}-0.0101 \\
(0.0072)\end{array}$ & $\begin{array}{l}-0.0030 \\
(0.0098)\end{array}$ & $\begin{array}{l}-0.0167^{*} \\
(0.0098)\end{array}$ & $\begin{array}{c}-0.0154^{*} \\
(0.0088)\end{array}$ & $\begin{array}{l}0.0006 \\
(0.0118)\end{array}$ & $\begin{array}{c}-0.0312^{\star *} \\
(0.0126)\end{array}$ \\
\hline $\begin{array}{l}\text { Children } \\
\text { (dummy) }\end{array}$ & $\begin{array}{l}-0.0273 \\
(0.0271)\end{array}$ & $\begin{array}{l}0.0341 \\
(0.0437)\end{array}$ & $\begin{array}{l}-0.0580^{*} \\
(0.0325)\end{array}$ & $\begin{array}{l}0.0079 \\
(0.0279)\end{array}$ & $\begin{array}{l}-0.0197 \\
(0.0426)\end{array}$ & $\begin{array}{l}0.0261 \\
(0.0356)\end{array}$ \\
\hline Town ${ }^{(1)}$ & $\begin{array}{c}-0.0105 \\
(0.0253)\end{array}$ & $\begin{array}{l}0.0012 \\
(0.0362)\end{array}$ & $\begin{array}{l}-0.0198 \\
(0.0325)\end{array}$ & $\begin{array}{l}-0.0556 \\
(0.0374)\end{array}$ & $\begin{array}{c}-0.0335 \\
(0.0577)\end{array}$ & $\begin{array}{l}-0.0519 \\
(0.0473)\end{array}$ \\
\hline Village $^{(1)}$ & $\begin{array}{l}-0.0457 \\
(0.0274)\end{array}$ & $\begin{array}{l}-0.0080 \\
(0.0366)\end{array}$ & $\begin{array}{c}-0.0792^{* *} \\
(0.0381)\end{array}$ & $\begin{array}{l}0.0314 \\
(0.0274)\end{array}$ & $\begin{array}{l}0.0556 \\
(0.0396)\end{array}$ & $\begin{array}{l}0.0025 \\
(0.0380)\end{array}$ \\
\hline Farm/countryside ${ }^{(1)}$ & $\begin{array}{l}0.0922 \\
(0.1374)\end{array}$ & $\begin{array}{l}0.0948 \\
(0.1349)\end{array}$ & 0 (omitted) & 0 (omitted) & 0 (omitted) & 0 (omitted) \\
\hline Income: coping ${ }^{(2)}$ & $\begin{array}{l}0.0489 \\
(0.0381)\end{array}$ & $\begin{array}{l}0.1015 \\
(0.0623)\end{array}$ & $\begin{array}{l}0.0152 \\
(0.0461)\end{array}$ & $\begin{array}{l}0.0040 \\
(0.0395)\end{array}$ & $\begin{array}{l}0.0754 \\
(0.0643)\end{array}$ & $\begin{array}{l}-0.0396 \\
(0.0489)\end{array}$ \\
\hline Income: difficult ${ }^{(2)}$ & $\begin{array}{l}0.0204 \\
(0.0425)\end{array}$ & $\begin{array}{l}0.0466 \\
(0.0701)\end{array}$ & $\begin{array}{l}0.0083 \\
(0.0505)\end{array}$ & $\begin{array}{l}-0.0005 \\
(0.0424)\end{array}$ & $\begin{array}{l}0.1012 \\
(0.0688)\end{array}$ & $\begin{array}{l}-0.0647 \\
(0.0521)\end{array}$ \\
\hline Income: v.difficult ${ }^{(2)}$ & $\begin{array}{r}0.0936^{* *} \\
(0.0443)\end{array}$ & $\begin{array}{r}0.1424^{\star \star} \\
(0.0715)\end{array}$ & $\begin{array}{l}0.0804 \\
(0.0538)\end{array}$ & $\begin{array}{l}0.0173 \\
(0.0475)\end{array}$ & $\begin{array}{l}0.0773 \\
(0.0763)\end{array}$ & $\begin{array}{c}-0.0136 \\
(0.0588)\end{array}$ \\
\hline Paid work ${ }^{(3)}$ & $\begin{array}{l}0.0191 \\
(0.0429)\end{array}$ & $\begin{array}{c}-0.0257 \\
(0.0512)\end{array}$ & $\begin{array}{l}0.1063 \\
(0.0709)\end{array}$ & $\begin{array}{l}0.0089 \\
(0.0649)\end{array}$ & $\begin{array}{c}0.0153 \\
(0.0811)\end{array}$ & $\begin{array}{c}-0.0113 \\
(0.1106)\end{array}$ \\
\hline Retired $^{(3)}$ & $\begin{array}{c}-0.0188 \\
(0.0472)\end{array}$ & $\begin{array}{c}0.0300 \\
(0.0610)\end{array}$ & $\begin{array}{c}-0.0446 \\
(0.0834)\end{array}$ & $\begin{array}{c}-0.0090 \\
(0.0675)\end{array}$ & $\begin{array}{l}0.0008 \\
(0.0852)\end{array}$ & $\begin{array}{l}0.0197 \\
(0.1158)\end{array}$ \\
\hline Homeworker ${ }^{(3)}$ & $\begin{array}{c}-0.0146 \\
(0.0453)\end{array}$ & $\begin{array}{c}-0.0854 \\
(0.1224)\end{array}$ & $\begin{array}{l}0.0397 \\
(0.0624)\end{array}$ & $\begin{array}{c}-0.0528 \\
(0.0669)\end{array}$ & 0 (omitted) & $\begin{array}{c}-0.0145 \\
(0.1042)\end{array}$ \\
\hline Ethnic minority & $\begin{array}{c}-0.0375 \\
(0.0434) \\
\end{array}$ & $\begin{array}{c}-0.1038 \\
(0.0692)\end{array}$ & $\begin{array}{c}0.0314 \\
(0.0524)\end{array}$ & $\begin{array}{c}-0.0259 \\
(0.0475) \\
\end{array}$ & $\begin{array}{c}-0.1470^{*} \\
(0.0828)\end{array}$ & $\begin{array}{c}0.0684 \\
(0.0583)\end{array}$ \\
\hline
\end{tabular}

Marginal effects, with standard errors in parentheses. Significance: $* * *_{p}<0.01$ : $* * p<0.05 * \mathrm{p}<0.10$. Omitted categories: $(1)$

Resident in big city; (2) comfortable with current income; (3) last 7 days any other activity. 
Table 4 Determinants of Voting for CHP (with religiosity)

\begin{tabular}{|c|c|c|c|c|c|c|}
\hline & \multicolumn{3}{|c|}{ ESS Wave 2 (2004) } & \multicolumn{3}{|c|}{ ESS Wave 4 (2008) } \\
\hline & 1 & 2 & 3 & 4 & 5 & 6 \\
\hline Male & $\begin{array}{c}-0.0711^{\star *} \\
(0.0301)\end{array}$ & & & $\begin{array}{c}-0.0746^{* *} \\
(0.0323)\end{array}$ & & \\
\hline Age & $\begin{array}{l}0.0111^{\star \star} \\
(0.0044)\end{array}$ & $\begin{array}{l}0.0117 \\
(0.0074)\end{array}$ & $\begin{array}{l}0.0092 \\
(0.0056)\end{array}$ & $\begin{array}{l}0.0072 \\
(0.0046)\end{array}$ & $\begin{array}{l}0.0136^{*} \\
(0.0079)\end{array}$ & $\begin{array}{l}0.0012 \\
(0.0055)\end{array}$ \\
\hline Age sqrd & $\begin{array}{l}-0.0001^{*} \\
(0.00004)\end{array}$ & $\begin{array}{l}-0.0001 \\
(0.0001)\end{array}$ & $\begin{array}{l}-0.0001 \\
(0.0001)\end{array}$ & $\begin{array}{l}-0.0001 \\
(0.0000)\end{array}$ & $\begin{array}{l}-0.0001 \\
(0.0001)\end{array}$ & $\begin{array}{l}0.0000 \\
(0.0001)\end{array}$ \\
\hline $\begin{array}{l}\text { Education years } \\
\text { sqrd }\end{array}$ & $\begin{array}{l}-0.0006 \\
(0.0004)\end{array}$ & $\begin{array}{l}0.0010 \\
(0.0007)\end{array}$ & $\begin{array}{l}-0.0013^{* *} \\
(0.0006)\end{array}$ & $\begin{array}{l}-0.0001 \\
(0.0005)\end{array}$ & $\begin{array}{l}0.0007 \\
(0.0008)\end{array}$ & $\begin{array}{l}0.0002 \\
(0.0007)\end{array}$ \\
\hline Household size & $\begin{array}{l}-0.0103 \\
(0.0070)\end{array}$ & $\begin{array}{l}-0.0035 \\
(0.0096)\end{array}$ & $\begin{array}{c}-0.0184^{\star *} \\
(0.0092)\end{array}$ & $\begin{array}{l}-0.0110 \\
(0.0086)\end{array}$ & $\begin{array}{l}0.0060 \\
(0.0115)\end{array}$ & $\begin{array}{l}-0.0274^{* *} \\
(0.0124)\end{array}$ \\
\hline $\begin{array}{l}\text { Children } \\
\text { (dummy) }\end{array}$ & $\begin{array}{l}-0.0146 \\
(0.0265)\end{array}$ & $\begin{array}{l}0.0500 \\
(0.0447)\end{array}$ & $\begin{array}{l}-0.0343 \\
(0.0308)\end{array}$ & $\begin{array}{l}-0.0064 \\
(0.0273)\end{array}$ & $\begin{array}{l}-0.0087 \\
(0.0412)\end{array}$ & $\begin{array}{l}-0.0096 \\
(0.0357)\end{array}$ \\
\hline Town $^{(1)}$ & $\begin{array}{l}-0.0146 \\
(0.0249)\end{array}$ & $\begin{array}{l}0.0029 \\
(0.0370)\end{array}$ & $\begin{array}{l}-0.0163 \\
(0.0306)\end{array}$ & $\begin{array}{l}-0.0448 \\
(0.0365)\end{array}$ & $\begin{array}{l}-0.0272 \\
(0.0549)\end{array}$ & $\begin{array}{l}-0.0421 \\
(0.0458)\end{array}$ \\
\hline Village $^{(1)}$ & $\begin{array}{c}-0.0352 \\
(0.0267)\end{array}$ & $\begin{array}{l}0.0063 \\
(0.0369)\end{array}$ & $\begin{array}{l}-0.0591^{*} \\
(0.0355)\end{array}$ & $\begin{array}{l}0.0330 \\
(0.0274)\end{array}$ & $\begin{array}{c}0.0765^{\star *} \\
(0.0388)\end{array}$ & $\begin{array}{l}-0.0148 \\
(0.0387)\end{array}$ \\
\hline Farm/countryside ${ }^{(1)}$ & $\begin{array}{l}0.0797 \\
(0.1398)\end{array}$ & $\begin{array}{l}0.0704 \\
(0.1421)\end{array}$ & 0 (omitted) & 0 (omitted) & 0 (omitted) & 0 (omitted) \\
\hline Income: coping ${ }^{(2)}$ & $\begin{array}{l}0.0358 \\
(0.0373)\end{array}$ & $\begin{array}{l}0.0928 \\
(0.0627)\end{array}$ & $\begin{array}{l}0.0050 \\
(0.0433)\end{array}$ & $\begin{array}{l}-0.0145 \\
(0.0399)\end{array}$ & $\begin{array}{l}0.0687 \\
(0.0653)\end{array}$ & $\begin{array}{l}-0.0583 \\
(0.0486)\end{array}$ \\
\hline Income: difficult ${ }^{(2)}$ & $\begin{array}{l}0.0083 \\
(0.0416)\end{array}$ & $\begin{array}{l}0.0394 \\
(0.0708)\end{array}$ & $\begin{array}{l}-0.0094 \\
(0.0479)\end{array}$ & $\begin{array}{l}-0.0162 \\
(0.0424)\end{array}$ & $\begin{array}{l}0.0921 \\
(0.0693)\end{array}$ & $\begin{array}{l}-0.0788 \\
(0.0515)\end{array}$ \\
\hline Income: v.difficult ${ }^{(2)}$ & $\begin{array}{l}0.0782^{*} \\
(0.0434)\end{array}$ & $\begin{array}{l}0.1229^{*} \\
(0.0721)\end{array}$ & $\begin{array}{l}0.0761 \\
(0.0507)\end{array}$ & $\begin{array}{l}-0.0035 \\
(0.0475)\end{array}$ & $\begin{array}{l}0.0784 \\
(0.0765)\end{array}$ & $\begin{array}{l}-0.0396 \\
(0.0585)\end{array}$ \\
\hline Paid work ${ }^{(3)}$ & $\begin{array}{l}0.0078 \\
(0.0416)\end{array}$ & $\begin{array}{l}-0.0397 \\
(0.0510)\end{array}$ & $\begin{array}{l}0.0866 \\
(0.0680)\end{array}$ & $\begin{array}{l}0.0007 \\
(0.0683)\end{array}$ & $\begin{array}{l}-0.0099 \\
(0.0794)\end{array}$ & $\begin{array}{l}0.0452 \\
(0.1295)\end{array}$ \\
\hline Retired $^{(3)}$ & $\begin{array}{l}-0.0241 \\
(0.0456)\end{array}$ & $\begin{array}{l}0.0192 \\
(0.0603)\end{array}$ & $\begin{array}{l}-0.0776 \\
(0.0799)\end{array}$ & $\begin{array}{l}0.0056 \\
(0.0707)\end{array}$ & $\begin{array}{l}-0.0030 \\
(0.0835)\end{array}$ & $\begin{array}{l}0.0736 \\
(0.1348)\end{array}$ \\
\hline Homeworker $^{(3)}$ & $\begin{array}{l}-0.0238 \\
(0.0435)\end{array}$ & $\begin{array}{l}-0.1025 \\
(0.1202)\end{array}$ & $\begin{array}{l}0.0374 \\
(0.0597)\end{array}$ & $\begin{array}{l}-0.0510 \\
(0.0705)\end{array}$ & 0 (omitted) & $\begin{array}{l}0.0545 \\
(0.1267)\end{array}$ \\
\hline Ethnic minority & $\begin{array}{l}-0.0318 \\
(0.0427)\end{array}$ & $\begin{array}{l}-0.1057 \\
(0.0695)\end{array}$ & $\begin{array}{l}0.0588 \\
(0.0483)\end{array}$ & $\begin{array}{l}-0.0395 \\
(0.0479)\end{array}$ & $\begin{array}{c}-0.2169^{\star \star \star} \\
(0.0829)\end{array}$ & $\begin{array}{l}0.0744 \\
(0.0560)\end{array}$ \\
\hline $\begin{array}{l}\text { Pray more than } \\
\text { once per week }\end{array}$ & $\begin{array}{c}0.0555^{\star} \\
(0.0322)\end{array}$ & $\begin{array}{l}0.0475 \\
(0.0420)\end{array}$ & $\begin{array}{l}0.0749^{*} \\
(0.0440)\end{array}$ & $\begin{array}{c}0.1208^{* * *} \\
(0.0330)\end{array}$ & $\begin{array}{c}0.1084^{* * *} \\
(0.0408)\end{array}$ & $\begin{array}{c}0.1211^{* *} \\
(0.0524)\end{array}$ \\
\hline $\begin{array}{l}\text { Pray } \\
\text { once per week }\end{array}$ & $\begin{array}{r}0.07415^{*} \\
(0.0404)\end{array}$ & $\begin{array}{l}0.0164 \\
(0.0558)\end{array}$ & $\begin{array}{c}0.1568^{\star \star \star} \\
(0.0554)\end{array}$ & $\begin{array}{c}0.1090^{* *} \\
(0.0420)\end{array}$ & $\begin{array}{c}0.1165^{\star \star} \\
(0.0551)\end{array}$ & $\begin{array}{l}0.0897 \\
(0.0630)\end{array}$ \\
\hline $\begin{array}{l}\text { Pray at least } \\
\text { once a month }\end{array}$ & $\begin{array}{l}0.1425^{\star \star} \\
(0.0558)\end{array}$ & $\begin{array}{l}0.1264^{*} \\
(0.0698)\end{array}$ & $\begin{array}{l}0.1191 \\
(0.0889)\end{array}$ & $\begin{array}{l}0.0458 \\
(0.0655)\end{array}$ & $\begin{array}{l}-0.0752 \\
(0.1301)\end{array}$ & $\begin{array}{l}0.0952 \\
(0.0748)\end{array}$ \\
\hline $\begin{array}{l}\text { Pray only on } \\
\text { Special holidays }\end{array}$ & $\begin{array}{l}0.0958 \\
(0.0720)\end{array}$ & 0 (omitted) & $\begin{array}{c}0.2445^{\star \star *} \\
(0.0926)\end{array}$ & $\begin{array}{c}0.1113^{* * *} \\
(0.0435)\end{array}$ & $\begin{array}{c}0.1949^{* * *} \\
(0.0690)\end{array}$ & $\begin{array}{l}0.0655 \\
(0.0529)\end{array}$ \\
\hline Pray less often & $\begin{array}{l}0.14051^{* * *} \\
(0.0470)\end{array}$ & $\begin{array}{l}0.0780 \\
(0.0684)\end{array}$ & $\begin{array}{c}0.1732^{* * *} \\
(0.0598)\end{array}$ & $\begin{array}{c}0.1982^{* * *} \\
(0.0606)\end{array}$ & $\begin{array}{c}0.2947^{* * *} \\
(0.0996)\end{array}$ & $\begin{array}{c}0.1625^{\star \star} \\
(0.0761)\end{array}$ \\
\hline Pray never & $\begin{array}{c}0.1958^{* * *} \\
(0.0493) \\
\end{array}$ & $\begin{array}{c}0.1598^{* * *} \\
(0.0603)\end{array}$ & $\begin{array}{r}0.2259^{* *} \\
(0.0890) \\
\end{array}$ & $\begin{array}{c}0.3008^{* * *} \\
(0.0485) \\
\end{array}$ & $\begin{array}{c}0.3042^{* * *} \\
(0.0703) \\
\end{array}$ & $\begin{array}{c}0.2832^{* * *} \\
(0.0651) \\
\end{array}$ \\
\hline
\end{tabular}

Marginal effects, with standard errors in parentheses. Significance: $* * * p<0.01$ : ${ }^{*} \mathrm{p}<0.05 * \mathrm{p}<0.10$. Omitted categories: $(1)$

Resident in big city; (2) comfortable with current income; (3) last 7 days any other activity. 


\section{Appendix A}

Descriptions of Independent Variables in the Empirical Analysis

\begin{tabular}{|c|c|}
\hline Name & Description \\
\hline Male & The gender of respondent: 1 if male and 0 if female. \\
\hline Age & Age of respondent \\
\hline Education years & Number of the years of education \\
\hline Household size & Number of household members \\
\hline Children & Children present in the household (dummy) \\
\hline Married/cohabitating & Respondent lives with husband/wife/partner \\
\hline Place of residence & $\begin{array}{l}\text { Place of residence, respondent's description: } \\
\text { 1: A big city (omitted category), } 2 \text { : Suburbs or outskirts of } \\
\text { big city, 3: Town or small city, } 4 \text { : Country village, } 5 \text { : Farm } \\
\text { or home in countryside }\end{array}$ \\
\hline Income & $\begin{array}{l}\text { Feeling about household's income nowadays: } \\
\text { 1: Living comfortably on present income (omitted } \\
\text { category), 2: Coping on present income, 3: Difficult on } \\
\text { present income, 4: Very difficult on present income }\end{array}$ \\
\hline Paid work & Doing last 7 days; paid work \\
\hline Student & Doing last 7 days; education \\
\hline Unemployed & Doing last 7 days; actively looking for a job \\
\hline Inactive & Doing last 7 days; not actively looking for a job \\
\hline Sick/disabled & Doing last 7 days; permanently sick or disabled \\
\hline Retired & Doing last 7 days; retired \\
\hline Homeworker & $\begin{array}{l}\text { Doing last } 7 \text { days; housework, looking after children, } \\
\text { others }\end{array}$ \\
\hline Ethnic & Belong to ethnic minority group in country \\
\hline Pray & $\begin{array}{l}\text { How often pray apart from religious services; } \\
\text { 1: Everyday (omitted category), } \\
\text { 2: More than once a week, } \\
\text { 3: Once a week, } 4 \text { : At least once a month, } \\
\text { 5: Only on special holidays, } \\
\text { 6: Less often, } \\
\text { 7: Never }\end{array}$ \\
\hline
\end{tabular}


Appendix B

The Results of 2002 and 2007 Turkish Elections

\begin{tabular}{|c|c|c|}
\hline & 2002 & 2007 \\
\hline Number of registered voters & 41407027 & 42799303 \\
\hline Number of Actual Voters & 32768161 & 36056293 \\
\hline Turnout Rate (\%) & 79.1 & 84.2 \\
\hline \multicolumn{3}{|l|}{ Vote Shares of Political Parties } \\
\hline Justice and Development Party (AKP) & 34.3 & 46.6 \\
\hline Motherland Party (ANAP) & 5.1 & --- \\
\hline Great Union Party (BBP) & 1.0 & --- \\
\hline Republican People's Party (CHP) & 19.4 & 20.9 \\
\hline Democratic People's Party (DEHAP) & 6.2 & --- \\
\hline Democratic Left Party (DSP) & 1.2 & --- \\
\hline True Path Party (DYP) & 9.5 & --- \\
\hline Virtue Party (FP) & --- & --- \\
\hline Young Party (GP) & 7.2 & 3.0 \\
\hline Nationalist Action Party (MHP) & 8.4 & 14.3 \\
\hline Felicity Party (SP) & 2.5 & 2.3 \\
\hline New Turkey Party (YTP) & 1.2 & --- \\
\hline Country Party (YT) & 0.9 & --- \\
\hline Independents & 1.0 & 5.2 \\
\hline Other & 2.0 & 7.7 \\
\hline
\end{tabular}

Source: Turkish Statistical Institute, Justice and Election Statistics, 2013, www.tuik.gov.tr 


\section{Appendix C}

Studies Examining the Gender Gap in Political Attitudes

\begin{tabular}{|c|c|c|}
\hline Study & Coverage and Data & Findings \\
\hline $\begin{array}{l}\text { Hayes } \\
(1997)\end{array}$ & $\begin{array}{l}\text { UK } \\
\text { (1992 British Election Survey) }\end{array}$ & $\begin{array}{l}\text { Gender does not have an impact } \\
\text { on votes. Feminism explains party } \\
\text { choice. }\end{array}$ \\
\hline $\begin{array}{l}\text { Chaney et al. } \\
\text { (1998) }\end{array}$ & $\begin{array}{l}\text { US } \\
\text { (1980, 1984, 1988, } 1992 \text { National } \\
\text { Election Studies) }\end{array}$ & $\begin{array}{l}\text { The main determinants of the } \\
\text { gender gap are economic } \\
\text { conditions, social programs, } \\
\text { military action, abortion and } \\
\text { ideology. }\end{array}$ \\
\hline $\begin{array}{l}\text { Studlar et al. } \\
\text { (1998) }\end{array}$ & $\begin{array}{l}\text { Australia, UK, US } \\
\text { (1993 Australian Election Survey, } \\
1992 \text { British Election Survey, } 1992 \\
\text { American National Election Survey) }\end{array}$ & $\begin{array}{l}\text { In Australia and the UK, } \\
\text { socioeconomic and situational } \\
\text { factors (women's adult } \\
\text { responsibilities) explain the gender } \\
\text { gap. In the US, political factors } \\
\text { have much more effect on the } \\
\text { gender gap. }\end{array}$ \\
\hline $\begin{array}{l}\text { Kaufmann and Petroick } \\
\text { (1999) }\end{array}$ & $\begin{array}{l}\text { US } \\
(1992,1996 \text { National Election } \\
\text { Surveys) }\end{array}$ & $\begin{array}{l}\text { Gender gap results from the } \\
\text { changing partisanship of men. } \\
\text { Differences in social welfare } \\
\text { opinions may be the main } \\
\text { contributor to the gender gap. }\end{array}$ \\
\hline $\begin{array}{l}\text { Inglehart and Norris } \\
(2000)\end{array}$ & $\begin{array}{l}60 \text { countries } \\
\text { (World Values Survey Data over } \\
\text { the period 1980s and 1990s) }\end{array}$ & $\begin{array}{l}\text { In postindustrial countries modern } \\
\text { gender gap persists while in } \\
\text { developing countries traditional } \\
\text { gender gap prevails. }\end{array}$ \\
\hline $\begin{array}{l}\text { Howell and Day } \\
(2000)\end{array}$ & $\begin{array}{l}\text { US } \\
\text { (1996 National Election Study) }\end{array}$ & $\begin{array}{l}\text { Egalitarian attitudes of women, } \\
\text { their cultural roles and education } \\
\text { are the main determinants of the } \\
\text { gender gap. }\end{array}$ \\
\hline $\begin{array}{l}\text { Knutsen } \\
\text { (2001) }\end{array}$ & $\begin{array}{l}\text { Denmark, Norway and Sweden } \\
\text { (Election Surveys from 1970s to } \\
\text { 1990s) }\end{array}$ & $\begin{array}{l}\text { Gender has an important effect on } \\
\text { voting behavior. Different sector } \\
\text { employment (public versus private) } \\
\text { explains part of the gender gap. }\end{array}$ \\
\hline
\end{tabular}


Appendix C (continued)

\begin{tabular}{|c|c|c|}
\hline Study & Coverage and Data & Findings \\
\hline $\begin{array}{l}\text { Kaufmann } \\
(2002)\end{array}$ & $\begin{array}{l}\text { US } \\
\text { (National Election Studies from } 1988 \\
\text { to 2000) }\end{array}$ & $\begin{array}{l}\text { Reproductive rights, female } \\
\text { equality, legal protection for } \\
\text { homosexuals are increasingly } \\
\text { significant determinants of party } \\
\text { identification for women. }\end{array}$ \\
\hline $\begin{array}{l}\text { Edlund and Pande } \\
\text { (2002) }\end{array}$ & $\begin{array}{l}\text { US } \\
\text { (National Election Studies, March } \\
\text { Current Population Surveys over the } \\
\text { period 1964-1996) }\end{array}$ & $\begin{array}{l}\text { Strong positive correlation between } \\
\text { divorce prevalence and the gender } \\
\text { gap. }\end{array}$ \\
\hline $\begin{array}{l}\text { Brooks et al. } \\
(2006)\end{array}$ & $\begin{array}{l}\text { Australia, Austria, Germany, The } \\
\text { Netherlands, UK and US } \\
\text { (International Social Cleavages and } \\
\text { Politics (ISCP) Data Set over the } \\
\text { period 1964-1998) }\end{array}$ & $\begin{array}{l}\text { With the exception of the US, } \\
\text { gender is not statistically significant } \\
\text { variable for explaining the voting } \\
\text { behavior. }\end{array}$ \\
\hline $\begin{array}{l}\text { Iversen and Rosenbluth } \\
\text { (2006) }\end{array}$ & $\begin{array}{l}\text { Australia, Canada, France, } \\
\text { Germany, Ireland, Norway, New } \\
\text { Zealand, Sweden, UK and US } \\
\text { (1996 International Social Survey } \\
\text { Program Data) }\end{array}$ & $\begin{array}{l}\text { In countries with high divorce rates, } \\
\text { working women vote for left parties. }\end{array}$ \\
\hline $\begin{array}{l}\text { Bergh } \\
(2007)\end{array}$ & $\begin{array}{l}\text { Netherlands, Norway, US } \\
\text { (1996 National Election Study for the } \\
\text { US, } 1996 \text { Euro Barometer Data for } \\
\text { the Netherlands and Citizenship } \\
\text { Survey from } 2000 \text { for Norway) }\end{array}$ & $\begin{array}{l}\text { In the US and in Norway, there is a } \\
\text { strong effect of feminist } \\
\text { consciousness on the gender gap. }\end{array}$ \\
\hline $\begin{array}{l}\text { Giger } \\
(2009)\end{array}$ & $\begin{array}{l}12 \text { Western Europe countries } \\
\text { (Euro Barometer, Eurostat, OECD, } \\
\text { Abramson and Inglehart (1995), } \\
\text { Huber et al. (2004) Data Sets over } \\
\text { the period 1974-2000) }\end{array}$ & $\begin{array}{l}\text { In } 1976 \text { and } 1985 \text {, women tended } \\
\text { to vote more for conservative } \\
\text { parties while in } 2000 \text { they have } \\
\text { given higher support to leftist } \\
\text { parties. The main determinant of } \\
\text { the modern gender gap is the } \\
\text { increasing labor force participation } \\
\text { of women. }\end{array}$ \\
\hline $\begin{array}{l}\text { Finseraas et al. } \\
\text { (2012) }\end{array}$ & Norway & $\begin{array}{l}\text { There is a gender gap in political } \\
\text { preferences. However, it cannot be } \\
\text { explained by the risk of women's } \\
\text { divorce. }\end{array}$ \\
\hline
\end{tabular}

